Свинаренко T. I., кандидат економічних наук, доцент кафедри фінансів, банківської справи та підприємництва, Донбаська державна машинобудівна академія, м. Краматорськ, Україна

ORCID ID: 0000-0003-4954-5784

e-mail: svtat@ukr.net

Гладкова О. В., кандидат економічних наук, доцент кафедри управління та економіки підприємства, Національний фармацевтичний університет, м. Харків, Україна

ORCID ID: 0000-0002-6029-9791

e-mail: olgladkova25@gmail.com

Формування та розвиток регіональних інноваційних систем: теорія, практика

Анотація. У статті визначено роль інноваційного напряму економічного розвитку у сучасних реаліях та доведено те, що саме національні інноваційні системи створюють передумови для активізації інноваційної діяльності підприємств пріоритетних галузей, сприяють їх дифузії в усі сфери соціально-економічного середовища, підвищують конкурентоспроможність національних виробників. Тому економічне зростання, досягнуте на основі інноваційного розвитку, сприятиме, по-перше, подальшому нарощуванню економічного потенціалу держави й темпів економічного розвитку, а по-друге, підвищенню рівня і якості життя населення, стабілізації ситуації в державі, забезпеченню їі економічної й соціальної безпеки. Розглянуто стан національної інноваційної системи, визначено тенденцію спаду інноваційної активності в Україні за даними міжнародних рейтингів та державної служби статистики Украйни, доведено наявну диференціацію регіонів за їх інноваційною активністю та інноваційним потенціалом. Обгрунтовано провідну роль регіональних складових у розвитку інноваційних процесів в країні та підвищенні ефективності інноваційної діяльності, визначено склад регіональних інноваційних систем, фактори та особливості їх формування та розвитку. Шляхом узагальнення наявного наукового та практичного досвіду щодо формування державної інноваційної стратегії та регіональних інноваційних систем надано пропозиції щодо формування сучасних інструментів інноваційного розвитку регіонів.

Ключові слова: національна інноваційна система; регіональна інноваційна система; регіональний інноваційний розвиток; трансфер інновацій.

Svynarenko Tatyana, Candidate of Sciences (Economics), Associate Professor, Department of Finance, Banking and Entrepreneurship, Donbass State Machine-Building Academy, Kramatorsk, Ukraine

Gladkova Olga, Candidate of Sciences (Economics), Associate Professor, Department of Management and Economics of Enterprise, National University of Pharmacy, Kharkiv, Ukraine

\title{
Formation and Development of Regional Innovation Systems: Theory, Practice
}

Abstract. Introduction. The article defines the role of the innovative direction of economic development in modern realities and proves that it is the national innovation systems that create the preconditions for activation of innovative activity of enterprises in priority industries, promote their diffusion into all spheres of socio-economic environment, increase the competitiveness of national producers. Therefore, the economic growth achieved on the basis of innovative development will, firstly, contribute to the further increase of the economic potential of the state and the pace of economic development, and secondly, to improving the level and quality of life of the population, stabilizing the situation in the country, ensuring its economic and social security.

Purpose. The state of the national innovation system is considered, the tendency of the innovation activity in Ukraine to decline according to the international ratings and the State Statistics Service of Ukraine is determined, the differentiation of the regions by their innovative activity and innovative potential is proved.

Results. It is stated that the national innovation system includes the innovative systems of its individual territories, which determine the effectiveness of its functioning and development. The leading role of regional components in the development of innovation processes in countries and increasing the efficiency of innovation activities is substantiated, the composition of regional innovation systems, factors and peculiarities of their formation and development are determined. There are four main subsystems: organizational-coordination, scientific-educational, business, infrastructure. These subsystems have different functions, but they are closely interconnected, complementary and must be designed according to the functional purpose of the regional innovation system.

Conclusions. By summarizing the existing scientific and practical experience in the formation of the state innovation strategy and regional innovation systems, proposals are made for the formation of modern instruments for innovative development of regions, taking into account and in accordance with the level of their socio-economic development and identified priorities, to the available financial, human and other resource opportunities. The application of such instruments in the practice of state and regional authorities will increase the competitiveness of regions and make effective use of their innovative potential. 

transfer.

Keywords: national innovation system; regional innovation system; regional innovation development; innovation

\section{JEL Classification: 018; 033.}

Постановка проблеми. Глобальні фінансовоекономічні впливи, конкуренція за ресурси та їх обмеженість доводять про актуальність пошуку новітніх підходів до управління розвитком держави та iï регіонів, які повинні забезпечити їх соціальноекономічний розвиток, конкурентоспроможність, фінансову та економічну безпеку. Особливої гостроти набувають проблеми щодо забезпечення інноваційного шляху розвитку та ефективного використання інноваційного потенціалу держави та її регіонів. Регіональний аспект інноваційного шляху розвитку має суттєве значення для України з їі значною територією та відмінностями соціально-економічного розвитку окремих територій. Хоча існують окремі позитивні результати функціонування, ступінь сформованості інноваційних систем у регіонах України в цілому низький, що зумовлено причинами інституційної неповноти, неузгодженості дій учасників інноваційних процесів, низьким технологічним рівнем виробничих систем і низької інноваційної активності підприємств. Регіонам необхідно чітко визначити інноваційні цілі відповідно до пріоритетних цілей і завдань регіонального розвитку, мобілізувати наявний інноваційний потенціал, сформувати інституційні та організаційні умови для переходу до інноваційного типу розвитку.

Аналіз останніх досліджень і публікацій. Питання інноваційного розвитку та управління інноваційними процесами, запровадження інноваційної моделі економічного розвитку активно досліджуються у працях: В. Александрова, О. Амосова, О. Амоші, С. Бендасюк, П. Бубенко, В. Головатюк, С. Горбалюк, І. Гагауз, А. Гальчинського, В. Гейця, В. Соловйова, Р. Фатхутдинової, Л. Федулової, А. Чухно, Й. Шумпетера та ін. У державі не вироблені зрозумілі організаційноекономічні механізми формування й реалізації регіональної інноваційної політики, немає адекватної поведінки державних і регіональних органів управління на виклики сучасної економіки, що вимагають підвищення ефективності інноваційного розвитку регіонів. Наявність нерозв'язаних проблем регіонального інноваційного розвитку вимагає подальшого дослідження у цьому напрямі.

Аналіз останніх наукових досліджень доводить про те, що інноваційний розвиток регіону безпосередньо залежить від його соціально-економічного становища та розв'язання проблемних питань регіонального зростання. Оскільки кожна територіальна одиниця має певні властивості й відмінні риси, зумовлені географічними, природними, економічними, соціальними та іншими чинниками його розвитку, формування механізмів їх інноваційного розвитку має враховувати ці особливості та відповідати пріоритетам розвитку окремих регіонів.
Формулювання цілей дослідження. Мета даного дослідження полягає в узагальненні наявного наукового та практичного досвіду щодо формування регіональних інноваційних систем та визначенні ефективних інструментів інноваційного розвитку регіонів, застосування яких дозволить підвищити конкурентоспроможність регіонів та ефективно використовувати їх інноваційний потенціал.

Виклад основного матеріалу дослідження. Під інноваційним типом розвитку розуміють спосіб економічного зростання, що базується на постійних $\mathrm{i}$ систематичних нововведеннях, спрямованих на суттєве поліпшення усіх аспектів діяльності господарської системи, для створення інноваційних товарів і формування їі конкурентних переваг, на періодичному перегрупуванні сил, обумовлений логікою НТП, цілями й завданнями розвитку системи, можливістю використання певних ресурсних факторів у створенні інноваційних товарів і формуванні конкурентних переваг [6, с.58-59].

У науковій літературі визначені загальні риси, які властиві інноваційному типу розвитку економіки, а саме: ключова роль наукових знань, висока якість освітньої системи, підтримання суспільством і державою нових ідей і технологій, впровадження інновацій різного функціонального спрямування, автоматизація та комп'ютеризація сфер виробництва й управління, реалізація комплексних програм розвитку підприємництва, регіонів, формування розвинутої інноваційної інфраструктури, ухвалення стратегічних управлінських рішень для виробництва та дифузії нововведень.

Для оцінки рівня інноваційного розвитку країни широко використовується інтегральна оцінка стану розвитку інноваційної системи країни, яка оцінює інноваційний потенціал, технологічну та інноваційну конкурентоспроможність країни за міжнародними рейтингами.

Глобальний індекс інновацій (Global Innovation Index) визначає оцінку інноваційного розвитку країни за 80 параметрами, включаючи огляд політичної ситуації, стан справ в освіті, рівень розвитку інфраструктури та бізнесу. За результатами оцінки у 2018 р. очолюють рейтинг провідних країн-новаторів: Швейцарія, Нідерланди, Швеція, Велика Британія та Сінгапур. Україна піднялася в рейтингу на сім позицій i посіла 43 місце зі 126 країн і територій світу. Основою української інноваційної конкурентоспроможності визначено людський капітал і дослідження, а також знання й результати наукових досліджень. Їх ефективна реалізація і $\epsilon$ головною конкурентною перевагою країни.

За рейтингом агентства Bloomberg щодо оцінки інноваційного розвитку країн на підставі ряду 
критеріїв, таких як витрати на НДДКР стосовно ВВП, відсоток інноваційних компаній у загальній кількості підприємств, кількість науковців на мільйон жителів, у 2019 р. Україна посіла лише 53-е місце в рейтингу (у 2018 р. країна займала 46-е місце).

Інноваційний індекс Європейського інноваційного табло (Innovation Union Scoreboard - IUS) відбиває основні індикатори оцінки ефективності функціонування національної інноваційної системи країн $Є С$. Позиції України стосовно середньоєвропейського рівня відповідають сьогодні рівню європейських аутсайдерів з інновацій (Румунія, Болгарія).

Глобальний індекс конкурентоспроможності талантів (Global Talent Competitiveness Index), який формують щорічно Міжнародна бізнес-школа INSEAD у партнерстві 3 Adecco Group та Інститутом лідерства людського капіталу (HCLI) Сінгапуру, розраховується на основі середнього арифметичного шести критеріїв: ринкові й нормативні умови на ринку праці; шанси для кар'єрного зростання; можливості роботодавців залучати таланти з усього світу, здатність утримувати кваліфікований персонал; виробничі навички співробітників і глобальні знання. Позиція України за Глобальним індексом конкурентоспроможності талантів у 2019 р. знизилася з 61-го місця до 63-го серед 125 країн.

Основними невирішеними проблемами, які перешкоджають активізації інноваційних процесів сьогодення, $\epsilon$ : недосконале та нестабільне законодавче забезпечення розвитку підприємництва у цілому, у тому числі інноваційного підприємництва, низький технологічний рівень виробництва, низька інноваційна активність суб'єктів підприємництва та нерозвиненість інноваційної інфраструктури, яка здатна створити необхідні умови для розвитку підприємництва в інноваційній сфері, слабке державне фінансування інноваційних розробок та дефіцит власних коштів підприємств на ведення інноваційної діяльності [11, с.77].

Сучасна нормативно-правова база України стосовно науково-технічної та інноваційної діяльності налічує близько 200 документів. Інноваційний шлях розвитку України задекларовано в стратегічних та програмних документах як державного, так і регіонального рівнів, зокрема, у розпорядженні Кабінету Міністрів України «Про схвалення Стратегії розвитку сфери інноваційної діяльності на період до 2030 року» [10]. Попри таку масштабність, чинне законодавче підґрунтя ще доволі далеке від світового рівня та вимог і дедалі більше не здійснює глибокого впливу на економічний та інноваційний розвиток країни. Аналіз показує, що стратегії соціальноекономічного розвитку регіонів розроблені «під копірку» й не вміщують особливості стратегічного аналізу кожної окремої території. Зазначене спричиняє появу стратегічних та тактичних прорахунків регіонального розвитку України [12, с.148].
Зазначимо, що поняття національної інноваційної системи (HIC), основні засади ї̈ формування та реалізації визначає «Концепція розвитку національної інноваційної системи», схвалена розпорядженням Кабінету Міністрів України від 17.06.2009 р. № 680-р. Документом не встановлено поняття регіональної інноваційної системи (PIC), механізму її формування й розвитку [7].

Рівень та тенденції розвитку інноваційності української економіки яскраво показують основні показники інноваційної діяльності промислових підприємств (табл.1).

Кількість інноваційно активних підприємств на кінець 2018 року складало лише 16,4\% у їх загальній кількості та $є$ нижчим за рівень 2012 року. Скорочення витрат промислових підприємств на інновації призвело до їх суттєвого скорочення у загальному обсязі реалізованої промислової продукції (більш ніж у два рази відносно до 2010 р.) при одночасному зростанні частки витрат на інновації у загальному обсязі реалізованої інноваційної продукції. У результаті маємо частку реалізованих інноваційних товарів і послуг у загальному обсязі реалізованої промислової продукції лише 0,8% (у 2010 р. - 3,8\%).

Аналіз інноваційної активності за регіонами України доводить їх значну диференціацію. Наприклад, за показником - кількість організацій, які здійснювали НДР у 2018 р., дві третини підприємств припадає на чотири області та м. Київ. Отже, якщо в цілому здійснювали НДР 950 підприємств, то 629 підприємств (або 66,2\% від загальної кількості) припадає на Харківську область (141 підприємство), Львівську область (72 підприємства), Дніпропетровську область (56 підприємств), Одеську область (46 підприємств) та м. Київ (314 підприємств).

Оцінка кількості працівників, долучених у виконанні НДР за рівнем освіти, показала, що кількість працівників, які мають вищу освіту по країні складає 76 тис. осіб із 88 тис. залучених у НДР, або 86,8 відсотка. Найвищий рівень виконавців НДР з вищою освітою у Львівській області - 93,3\%, в Харківській області - 89,9\%, в Дніпропетровській області - 86,6\%, у м. Київ - 86,4\%, в Запорізькій області - 73,9 відсотка (2893 із 3913 працівників).

Кількість працівників, залучених у виконанні НДР у 2018 р. склала 88128 осіб, майже половина наукового потенціалу зосереджено у м. Київ - 40113 осіб (45,5\%), друге місце посідає Харківська область - 14226 осіб $(16,1 \%)$, далі йдуть Дніпропетровська - 8658 осіб (9,8\%), Запорізька - 3913 осіб (4,4\%), Одеська - 2548 осіб (2,9\%) [5]. Достатньо високий науковий, освітній потенціал та рівень інноваційної активності має лише м. Київ, далі за лідером іде Харківська область у частині наукового потенціалу та на рівні зі столицею за інноваційною активністю. Ця активність спричинена кількістю підприємств, що займаються інноваційною діяльністю, кількістю освоєних нових технологічних процесів, видів продукції, машин, устаткування. 
Таблиця 1 Основні показники інноваційної діяльності промислових підприємств України у 2010-2018 рр.

\begin{tabular}{|c|c|c|c|c|c|}
\hline$\frac{\text { Роки }}{\text { Показники }}$ & 2010 & 2012 & 2014 & 2016 & 2018 \\
\hline $\begin{array}{l}\text { Кількість інноваційно активних промислових підприємств, } \\
\text { усього, од. }\end{array}$ & 1462 & 1758 & 1609 & 834 & 777 \\
\hline \% до загальної кількості промислових підприємств & 13,8 & 17,4 & 16,1 & 18,9 & 16,4 \\
\hline Витрати на інновації, усього, млн грн & 8045,5 & 11480,6 & 7695,9 & 23229,5 & 12180,1 \\
\hline $\begin{array}{l}\text { \% до загального обсягу реалізованої промислової продукції } \\
\text { (товарів, послуг) }\end{array}$ & 0,9 & 1,0 & 0,8 & 0,7 & 0,4 \\
\hline $\begin{array}{l}\text { \% до загального обсягу реалізованої інноваційної продукції } \\
\text { (товарів, послуг) }\end{array}$ & 23,9 & 31,8 & 30,0 & $*$ & 49,0 \\
\hline $\begin{array}{l}\text { Кількість промислових підприємств, що впроваджували } \\
\text { інновації (продукцію та/або технологічні процеси), усього од. }\end{array}$ & 1217 & 1371 & 1208 & 735 & 739 \\
\hline \% до загальної кількості промислових підприємств & 11,5 & 13.6 & 12.1 & 16,6 & 15.6 \\
\hline $\begin{array}{l}\text { Кількість упроваджених у виробництво нових технологічних } \\
\text { процесів, усього од. }\end{array}$ & 2043 & 2188 & 1743 & 3489 & 2002 \\
\hline $\begin{array}{l}\text { з них нових або суттєво поліпшених маловідходних, } \\
\text { ресурсозберігаючих, \% }\end{array}$ & 23,4 & 25,3 & 25,6 & 21,4 & 46,3 \\
\hline $\begin{array}{l}\text { Кількість упроваджених видів інноваційної продукції (товарів, } \\
\text { послуг) усього од. }\end{array}$ & 2408 & 3403 & 3661 & 4139 & 3843 \\
\hline з них нових видів машин, устаткування, приладів, апаратів, \% & 27,5 & 27,7 & 35,9 & 31,5 & 23,9 \\
\hline $\begin{array}{l}\text { Обсяг реалізованої інноваційної продукції (товарів, послуг), } \\
\text { усього, млн грн }\end{array}$ & 33697,6 & 36157,7 & 25669,0 & $*$ & 24861,1 \\
\hline $\begin{array}{l}\text { \% до загального обсягу реалізованої промислової продукції } \\
\text { (товарів, послуг) }\end{array}$ & 3,8 & 3,3 & 2,5 & $*$ & 0,8 \\
\hline
\end{tabular}

Джерело: за даними Державної служби статистики (розрахунок показника не здійснювався) [9]

Зазначимо, що спочатку теоретики й практики інноваційних систем зосереджували увагу здебільшого на національному рівні, не розглядаючи регіональні чинники, які впливають на інноваційну діяльність та викликають різні нові явища та процеси. Наукові дослідження свідчать, що знання та інновації сконцентровані в окремих регіонах. Це пояснюється тим, що ключові елементи інноваційного процесу мають здебільшого регіональний характер, а просторова близькість прискорює появу інновацій. Крім того, коли суб'єкти знань і досвіду, а також суб'єкти, які передають свої знання і досвід, сконцентровані географічно, використання цих ресурсів відбувається найбільш ефективно $[3,4]$.

Тому з 90-х рр. XX ст. науковці наголошують на важливості локального рівня інноваційних процесів i визначають саме регіон як місце створення i стимулювання інновацій. Поняття регіональної інноваційної системи (PIC) одним із перших ввів британський дослідник Ф. Кук у статті «Регіональні інноваційні системи: конкурентна політика в новій Європі». Існуючі сьогоденні підходи до розуміння національних інноваційних систем (НIC) і регіональних інноваційних систем (PIC) мають багато спільного.

У науковій літературі PIC, найчастіше, визначено як складну, відкриту, динамічну, організовану соціальноекономічну систему, що складається з розташованих у межах регіону підприємств, установ, організацій, органів державної влади, органів місцевого самоврядування, громадян, які цілеспрямовано взаємодіють між собою у сфері створення, поширення, використання нових знань і технологій, виробництва та реалізації інноваційної продукції й послуг $[4,8]$. Сьогодні регіональні інноваційні системи являють собою локалізовані на території окремих регіонів групи, що рефлексивно взаємодіють 3 підприємствами, організаціями, установами, які об'єдналися на основі спільних інтересів забезпечення ефективного інноваційного процесу на основі ефективного використання ресурсів та єдиного регіонального простору [1, с. 209].

Групування елементів РІС дозволило виділити ії основні підсистеми: організаційно-координаційну, науково-освітню, підприємницьку, інфраструктурну. Ці підсистеми виконують різні функції, але вони тісно взаємопов'язані між собою, є взаємодоповнюючими та повинні формуватися за функціональним призначенням PIC.

Визначальна роль у цієї системі відводиться організаційно-координаційній підсистемі. Вона включає регіональні органи влади, які: визначають стратегію розвитку РІC; забезпечують цільову орієнтацію та координацію функціонування суб'єктів системи; створюють умови щодо поліпшення інвестиційного та інноваційного клімату для залучення інвестицій в інноваційну сферу; застосовують щодо всіх учасників PIC методів як прямого та непрямого стимулювання інноваційного розвитку шляхом підтримки науково-дослідної діяльності, яка відповідає цілям розвитку регіону; здійснює реальну підтримку розвитку високотехнологічних галузей промисловості та сфери послуг. 
Науково-освітня підсистема РІС представлена спеціалізованими науково-дослідними інститутами, науковими центрами, навчальними закладами, а також підприємствами та організаціями регіону, які проводять науково-дослідну діяльність 3 метою підвищення конкурентоспроможності своєї продукції та регіону в цілому.

Підприємницька підсистема РІС представлена суб'єктами господарювання, які своїм коштом чи за допомогою позикових коштів впроваджують інновації; власниками інтелектуальної власності (автори винаходів, промислових зразків, проєктів, установок, технологічних процесів, дизайнерів, тощо), реалізованої в процесі інноваційної діяльності; а також інвесторами, які фінансують інноваційні проєкти (корпорації, лізингові фірми, фінансово-промислові групи тощо). Саме підприємницька підсистема безпосередньо здійснює виробництво інновацій (товарів і послуг), їх просування та реалізацію.

Інфраструктурна підсистема PIC передбачає трансфер та комерціалізацією інновацій, а також надання різних видів підтримки процесу розробки та впровадження інновацій. Вона передбачає наявність таких регіональних інноваційних структур, діяльність яких сприяє розвитку інноваційного потенціалу регіону: бізнес-інкубатори, індустріальні парки, технопарки, інноваційно-промислові комплекси, інноваційно-технологічні центри, мережі трансферу технологій, а також фінансові інститути, що включають бюджетні, інноваційні, страхові, венчурні та інші фінансові фонди й компанії [3, 4]. Формування та функціонування РIC вимагає використання комплексу інструментів, які відповідатимуть функціональному змісту кожної із ії підсистем: інституційних, правових, фінансових, організаційних, мотиваційних, аналітичних, інформаційних, які утворюють механізм функціонування та розвитку відповідних РІС. Загальний склад та види таких інструментів широко представлені в наукових публікаціях та використовуються на практиці [1-8].

Водночас науковці наполягають на тому, що РІС для окремого регіону не $€$ зменшеною копією НІС чи «еталоном» для інших територіальних інноваційних систем. Зміст і функції окремої РІС визначаються наявним тільки на даній адміністративнотериторіальній одиниці інституціональним середовищем, регіональним ресурсним та інноваційним потенціалом, рівнем розвитку економіки та соціальної сфери, економічною та інноваційною регіональною інфраструктурою. Відтак для кожного регіону необхідна власна науковотехнічна та інноваційна політика, що враховує особливості розвитку та наявні ресурсні можливості територій. Тому й сукупність інструментів для забезпечення ефективного функціонування окремих PIC має бути відповідною пріоритетам розвитку саме цих регіонів з урахуванням наявного економічного та інноваційного потенціалу.
Наприклад, для регіонів, які займають лідируючи позиції за активністю в інноваційній сфері, доцільне формування стратегії комплексного інноваційного розвитку, заснованої на створенні власних та впровадженні наявних інновацій шляхом формування інноваційних кластерів, які об'єднують виробничі, науково-дослідні та освітні інститути. Інструментами реалізації інноваційної стратегії в таких регіонах мають бути: розвиток інноваційно-орієнтованих та індустріальних технопарків; формування регіональних органів влади та управління, які здійснюватимуть координацію діяльності учасників кластерів; реалізація великих інноваційних проєктів у рамках створених кластерів.

Для регіонів, які відрізняються активністю розробок інноваційних продуктів, доцільні інвестиції в людські ресурси; розвиток системи дифузії інновацій; горизонтальні та вертикальні переливи капіталів. Інструментами реалізації стратегії $€$ : маркетинговоорієнтовані технопарки; інтеграція основних агентів розвитку повного циклу інновацій (університетів, бізнесу, наукових установ та інше); створення центрів наукової інформації, що акумулюють права інтелектуальної власності [2, с.68].

Для регіонів, активних у виробництві інноваційної продукції, доцільно використовувати стратегію широкого впровадження інновацій. У складі необхідних інструментів доцільно використання: інжиніринго-консалтингових центрів, які здійснюють широкий спектр науково-технічних послуг; інвестиційно-орієнтованих технопарків, що забезпечують зв'язок регіональних виробничих та інших структур 3 потенційними зарубіжними інвесторами, тощо.

Для регіонів, що відрізняються низьким рівнем інноваційному розвитку, найбільш доцільною $€$ стратегія точкового впровадження інновацій, яка реалізується за допомогою: формування «точок зростання» в регіонах на базі тих підприємств, які $€$ найбільш розвиненими; підвищення інноваційної сприйнятливості органів влади й управління, бізнесструктур, населення регіонів; створення галузевих виробничих комплексів; залучення зарубіжних інвесторів [2, с. 70].

При визначенні основних напрямів впровадження комплексу механізмів формування РIC необхідно передбачити об'єднання зусиль і ресурсів органів влади різних рівнів, спрямованих на вдосконалення взаємодії між собою, а також усіх підсистем PIC у єдиний механізм в інтересах формування інноваційного напряму економічного розвитку регіонів. Ефективність РІС слід оцінювати через системну взаємодію цих різних інструментів.

Висновки. У рамках НІС на макрорівні формуються загальні умови, правила та інституції, що утворюють середовище розвитку інноваційної діяльності всіх суб'єктів національної економіки. Процес створення нових знань фокусується на регіональному рівні, де 
існує адекватна інфраструктура їх створення, акумуляції, подальшого поширення та використання. Тому саме регіони виступають ключовим елементом та рушійною силою розвитку інноваційних процесів, а ефективний розвиток НІС можливий на базі ефективного розвитку ії регіональних складових - РІС. Механізм щодо реалізації інноваційного шляху розвитку регіонів повинен враховувати значну їх диференціацію як за рівнем соціально-економічного розвитку, так й наявним інноваційним потенціалом, бути адекватним можливостям та пріоритетам розвитку конкретного регіону. Стратегічним документом у формуванні й подальшому розвитку РІС повинна бути інноваційна стратегія конкретного регіону, кінцевим результатом якої повинно бути підвищення його конкурентоспроможності та забезпечення сталого розвитку.

\section{Література:}

1. Бендасюк С. П. Формування та розвиток регіональних інноваційних систем. Культура народов Причерноморья. 2014. № 273. С. 207-210.

2. Бендасюк С. П. Принципи, стратегії, інструментарій управління інноваційним розвитком підприємств харчової промисловості. АГРОСВІТ. 2015. № 34. С. 66-70.

3. Горблюк С. А. Сутність та ключові характеристики регіональної інноваційної системи. Вісник НАДУ. 2014. № 3. С. 137144.

4. Горблюк С. А. Структурно-функціональна модель регіональної інноваційної системи. Ефективність державного управління : зб. наук. пр. Львів. регіон. ін-ту держ. упр. Нац. акад. держ. упр. при Президентові України. 2015. № 45. С. $183-190$.

5. Державна служба статистики України : веб-сайт. URL: http://www.ukrstat.gov.ua (дата звернення 11.02.2020).

6. Інноваційний менеджмент: теорія і практика в умовах трансформації економіки : навч. посібник / В. І. Захарченко, Н. М. Корсікова, М. М. Меркулова. К. : Центр учбової літератури, 2012. 448 с.

7. Концепція розвитку національної інноваційної системи: схвалено розпорядженням Кабінету Міністрів України від 17.06.2009 p. N 680-p. URL: https://zakon.rada.gov.ua/laws/show/680-2009-\%D1\%80. (дата звернення 11.02.2020).

8. Мартьянов М.П. Регіональна інноваційна інфраструктура як один з ключових елементів регіональної інноваційної системи. Вісник Вінницького політехнічного інституту. 2016. URL: https://conferences.vntu.edu.ua/index.php/all$\mathrm{fm} / \mathrm{all} . . . / 420$ (дата звернення 11.02.2020).

9. Наукова та інноваційна діяльність України. Статистичний збірник / Відп. за вип. Кузнєцова М. С. К. : Державна служба статистики України, 2019. 107 с.

10. Про схвалення Стратегії розвитку сфери інноваційної діяльності на період до 2030 року : схвалено розпорядженням Кабінету міністрів України від 10 липня 2019 р. № 526-p. URL: https://zakon.rada.gov.ua/laws/show/526-2019-\%D1\%80 (дата звернення: 11.02.2020).

11. Стан інноваційної діяльності та діяльності у сфері трансферу технологій в Україні у 2018 році: аналітична довідка / Т. В. Писаренко та ін. К. : УкрIHTEI, 2019. 80 с.

12. Федулова Л. І. Формування регіональних інноваційних систем у контексті принципів європейської інноваційної політики. Академічний огляд. 2014. №1. С.144-155.

\section{References:}

1. Bendasiuk, S. P. (2014). Formation and development of regional innovation systems. Kul'tura narodov Prychernomor'ia. 273, 207-210 [in Ukrainian].

2. Bendasiuk, S. P. (2015). Principles, strategies, tools for managing the innovative development of food industry enterprises. AHROSVIT, 34, 66-70 [in Ukrainian].

3. Horbliuk, S. A. (2014). The essence and key characteristics of the regional innovation system. Visnyk NADU, 3, 137-144 [in Ukrainian].

4. Horbliuk, S. A. (2015). Structural and functional model of regional innovation system.. Efektyvnist' derzhavnoho upravlinnia : zb. nauk. pr. L'viv. rehion. in-tu derzh. upr. Nats. akad. derzh. upr. pry Prezydentovi Ukrainy, 45, 183-190 [in Ukrainian].

5. State Statistics Service of Ukraine (2020). Official web-site. Retrieved from http://www.ukrstat.gov.ua [in Ukrainian].

6. Zakharchenko, V. I., Korsikova, N. M. \& Merkulova, M. M. (2012). Innovatsijnyj menedzhment: teoriia i praktyka v umovakh transformatsii ekonomiky. K. : Tsentr uchbovoi literatury [in Ukrainian].

7. Cabinet of Ministers of Ukraine (2009). Concept of development of national innovation system (Decree No. 680-r, June 17). Retrieved from https://zakon.rada.gov.ua/laws/show/680-2009-\%D1\%80. [in Ukrainian].

8. Mart'ianov, M. P. (2016). Regional innovation infrastructure as one of the key elements of a regional innovation system. Visnyk Vinnyts'koho politekhnichnoho instytutu. Retrieved from https://conferences.vntu.edu.ua/index.php/all-fm/all.../420 [in Ukrainian].

9. Kuznietsova, M. S. (2019). Naukova ta innovatsijna diial'nist' Ukrainy. Statystychnyj zbirnyk. K.: Derzhavna sluzhba statystyky Ukrainy [in Ukrainian].

10. Cabinet of Ministers of Ukraine. (2019). On approval of the Strategy for development of the sphere of innovative activity for the period till 2030 (Decree No. 526-r, July 17). Retrieved from https://zakon.rada.gov.ua/laws/show/526-2019-\%D1\%80 [in Ukrainian].

11. Pysarenko, T. V. (2019). Stan innovatsijnoi diial'nosti ta diial'nosti u sferi transferu tekhnolohij v Ukraini u 2018 rotsi. K.: UkrINTEI [in Ukrainian]. 
Електронне наукове фахове видання з економічних наук “Modern Economics», №20 (2020), 239-245 https://modecon.mnau.edu.ua | ISSN 2521-6392

12. Fedulova, L. I. (2014). Formation of regional innovation systems in the context of the principles of european innovation policy. Akademichnyj ohliad. 1, 144-155 [in Ukrainian]. 